\title{
Contribution of Social Support to Work-life Balance on Working Women During Work From Home
}

\author{
Rezky Ariany Aras ${ }^{1}$, Sri Wahyuni ${ }^{2}$ \\ Annisa Halawatus Salwa Thalib ${ }^{3 *}$
}

\author{
${ }^{1}$ Psychology Department, Faculty of Medicine, Hasanuddin University \\ ${ }^{2}$ Psychology Department, Faculty of Medicine, Hasanuddin University \\ ${ }^{3}$ Psychology Department, Faculty of Medicine, Hasanuddin University \\ *Corresponding author Email: salwathalib@yahoo.co.id
}

\begin{abstract}
The switch to work from home during the covid-19 pandemic has affected people's work-life balance, even more so for working women. This study aims to determine the contribution of social support to work-life balance on working women during work from home. This research uses a quantitative method with a causality correlational design. Subjects in this study amounted to 171 respondents of working women. Measuring instruments used are the social support scale and a work-life balance scale. This study indicates a contribution of social support to work-life balance on working women during work from home; $r$ 0,466 ( $p<0,001)$. In addition, the $\mathrm{R}$ square value is 0,217 . The relationship between social support and work-life balance has a positive direction. The higher social support working women get, their work-life balance will be increased. This study also shows that the work-life balance of working women who have two children is in the high category and the work-life balance of working women with an age group of more than 40 years is in the high category.
\end{abstract}

Keywords: Work-Life Balance, Social Support, Working Women

\section{INTRODUCTION}

All countries in the world are currently shocked by the global pandemic of the COVID-19 virus. COVID- 19 is a threat to all organizations due to changes in work methods and human interactions. The work method applied assigns duties and responsibilities to employees by doing work from home [1]. This change in work methods was carried outas an alternative strategy to prevent the spread of the COVID-19 virus. Work from home has an impact on all workers. In Indonesia, there is a paradigm that women are the most responsible for doing household chores. Situations like this make a work-life balance even more critical to have.

Research conducted in America states that $65 \%$ of working women have a bleak future. The pressure of the role as workers makes it easy to conflict because of their stress. Women tend to bring them into work-family conflict [2].
Fisher, Smith, \& Bulger [3] explain that when work interferes or interferes with personal life, it will disrupt the work-life balance of individuals. So it is essential to maintain a balance between these two roles to avoid conflict. The existence of demands from the role played by workers, if not appropriately managed, could cause various impacts. Low worklife balance can impact decreasing productivity and increasing turnover [4].

Barnett \& Hyde [5] suggest that the benefits of achieving work-family balance for workers are improving a person's quality of life, protecting against the negative impacts of one role, and balancing two roles. Hudson [6] suggests that someone who has a lower level of conflict between work and life can have higheroverall job satisfaction.

Based on this, it is known that working women who can balance work and personal life roles can avoid conflicts between work and life. However, 
preliminary data from interviews and surveys show that when doing work from home, several obstacles occur, such as irregular working hours resulting in difficulties for workers to manage time to complete homework and office work, role conflicts due to demands complete first. Housework (taking care of children and house) so that office work is done when the homework has been done. The impact also felt is that workers find it difficult to complete work and work demands that exceed capacities.

The work-life balance consists of various determinants such as values, personality, aspects related to work (working hours and working conditions), aspects related to the household (child care, household chores, cleanliness), free time, and more [7]. The factors that affect work-life balance are individual factors (personality, well-being, emotional intelligence), organizational factors (work arrangements, work-life balance policies, and programs, work support, job stress, technology, role-related factors), societal factors (childcare responsibilities, family support), and others societal factors.

The survey results showed that one factor that hinders employees from balancing their roles is support from the environment, such as family and co-workers. Families are less involved in completing homework and lack discussion and appreciation from co-workers.

Weiss [8] defines social support as an individual's need to get comfort, attention, and encouragement from others, which can help individuals overcome the difficulties experienced in their lives. The forms of social support that can be provided are in the form of emotional support (empathy, caring, and caring), appreciation support (positive assessment), instrumental support (direct assistance), informative support (giving advice, instructions, suggestions, and feedback), and social network support (accepted as part of the group).

Individuals who receive social support from the surrounding environment tend to experience lower stress levels and more easily cope with these depressed conditions than those who lack social support [9]. Adnyaswari \& Gusti [10] also state that the social support obtained will make individuals feelconfident that they are loved and appreciated to reduce burnout symptoms.

In the family context, partner support such as the partner's participation in helping complete household chores, taking care of children, and listening to complaints can reduce the burden on women whowork. Social support obtained from the family is considered a significant factor in making workers more positive and positively impacting performance [11].

In the context of co-workers, the support provided can make individuals optimal in doing their work. Co-workers can make workers happier and motivated to be more productive [11]. This is also supported by research conducted by Tajriani that the social support of colleagues has a significant effect on employee performance. When workers get support from their co-workers, individual performance will improve. Research conducted by Adnyaswari \&Gusti [10] shows that social support obtained from superiors and co-workers positively influences nurse performance.

Based on the results of interviews and surveys, work from home makes relationships with coworkersincreasingly distant because workers are less open to each other, so socialization related to work is reduced. Workers feel that they do not get support and appreciation for their work, so the quality and quantity of work decreases. In addition, family as the closest environment during work from home doesnot provide optimal support. This is indicated by The partner's behavior who does not contribute to helping the housework inhibits the individual from completing his work [12].

Based on the research results conducted by Greenhaus, Ziegert, \& Allen [13], there is a contribution between social support and work-life balance, where individuals will more easily achieve work-family balance if they have a supportive husband of their work. Support from the husband can be in the form of providing advice and understanding when the wife has work problems. The research results by Novenia and Ika [14] show a positive and significant contribution between husband's social support and work-family balance for female teachers at SMA Negeri Purworejo. The higher the husband's level of social support, the higher the work-family balance. Conversely, low social support from husbands will result in low work-family balance for female teachers.

All of these studies show that social support contributes to the work-life balance of female workers. The results of these studies are supported by data from interviews and surveys regarding the relationship between social support and work-life balance. Based on the interview results, it was found that the lack of social support provided by the environment caused workers to experience role conflicts and impacted the quality and quantity of their work. 


\subsection{Work-Life Balance}

Work-life balance is the extent to which individuals feel involved and satisfied in a balanced way in their roles in work life and personal life [5]. Fisher, Smith, \& Burger [3] also explain that worklife balance is the extent to which work interferes with personal life, personal life interferes with work, work improves personal life, and personal life increases work. Fisher, Smith, \& Bulger [3] explain that when work interferes or interferes with personal life, it will disrupt the work-life balance of individuals.

Fisher, Smith, \& Burger [3] suggest that there are four dimensions of work-life balance, such as (1) Work Interference with Personal Life (WIPL), which refers to the extent to which work can interfere with an individual's personal life. For example, work can make it difficult for individuals to manage time for their personal lives; (2) Personal Life Interference withWork (PLIW) refers to the extent to which personal life interferes with work life. For example, when an individual has problems in his personal life, it can interfere with the individual's performance at work; (3)Personal Life Enhancement of Work (PLEW) refers to the extent to which an individual's personal life canimprove an individual's performance in the world of work. For example, if a person feels happy because his personal life is pleasant, then that will make that person feel happy at work; (4) Work Enhancement of Personal Life (WEPL) refers to how work can improve the quality of an individual's personal life. For example, individuals' skills in the workplace enable them to use these skills in everyday life.

\subsection{Social Support}

Weiss [8] defines social support as an individual's need to get comfort, attention, and encouragement from others, which can help individuals overcome the difficulties experienced in their lives. Uchino [15] states that social support is that individuals get comfort, care, respect, and assistance from other people or groups. Cobb [16] also suggests that social support is the perception of comfort, care, appreciation, or assistance obtained by individuals to directly feel the support provided, such as feeling cared forand loved.

House [16] suggests four dimensions of social support, such as (1) Emotional support; this support includes empathy, care, and concern for individuals so that individuals who receive support will feel that they are loved, cared for, and feel comfortable ; (2) Appreciation Support, this support includes a positive assessment of the individual on the person's ideas, feelings, and positive comparisons withothers;
(3) Instrumental Support, this support includes direct assistance provided as needed by the recipient of the support; and (4) Information Support, this support includes the provision of advice, instructions, suggestions or feedback.

\subsection{Work-Life Balance and Social Support}

The relationship between the two variables can be explained using the Conservation of Resources theory. Conservation of Resources Theory It is the basic motivational principle that individuals seek to acquire and protect their personal and environmental resources and will be stressed when circumstances threaten or result in the loss of these resources. Based on this, stress can occur in three circumstances, first when there is a threat and loss of resources. Second, when resources are lost, and third, when there is a failure to obtain resources commensurate with the previous investment. Resources can be defined as objects (cars, houses, and other objects), conditions (job security, good marriage), personal characteristics (beliefs, skills), and energies (money, knowledge, help owed) that individuals value or that serve as a means of to obtain what is valued by individuals [7]. Resources are divided into personal resources and environmental resources. Personal resources include values, locus of control, optimism, and other characteristicsmeanwhile, environmental resources such as autonomy, feedback, and social support [7].

\section{METHOD}

\subsection{Samples}

The sampling technique in this study used accidental sampling. The population in this study were working women in Makassar City. The subjects in this study have the following characteristics: private workers/employees who work from home, working women who are married and domiciled in Makassar.

\subsection{Measurement}

\subsubsection{Dependent Variable}

The work-life balance scale consists of 17 statement items divided into six favorable and 11 unfavorable items. This scale uses a Likert scale consisting of five answer choices. This scale was developed by Fisher, Bulger \& Smith [3] and adapted into Indonesian by Ummah [17]. The validity test result was that the RMSEA value was $0.071 \leq 0.08$, and the Cronbach's alpha reliability value was 0.822 . 


\subsubsection{Independent variable}

The social support scale consists of 28 statement items divided into 13 favorable and 15 unfavorable items. This scale uses a Likert scale consisting of four answer choices. This scale was compiled by Caesaria (2010) based on House theory [16] and has been modified by Mithayani (2021). The validity test result was that the RMSEA value was $0.078 \leq$ 0.08 , and the Cronbach's alpha reliability value was 0.886 .

\section{RESULT}

\subsection{Descriptive Analysis}

Based on the test results using statistics, the minimum, maximum, mean, and standard deviation values for each variable is shown below.

Table 1. Descriptive Statistics

\begin{tabular}{lcccc}
\hline \multicolumn{1}{c}{ Variable } & $\begin{array}{c}\text { Min. } \\
\text { Value }\end{array}$ & $\begin{array}{c}\text { Max. } \\
\text { Value }\end{array}$ & Mean & SD \\
$\begin{array}{l}\text { Work-Life } \\
\text { Balance }\end{array}$ & 41 & 83 & 66.01 & 8.84 \\
\hline $\begin{array}{l}\text { Social } \\
\text { Support }\end{array}$ & 60 & 112 & 93.67 & 10.97 \\
\hline
\end{tabular}

\subsection{Descriptive Analysis}

Hypothesis testing was performed using simple regression analysis. Based on the acquisition of research data, the results of the research hypothesis test are as follows.

Table 2. Regression Analysis

\begin{tabular}{|c|c|c|c|c|}
\hline Variable & $\mathbf{R}$ & $\mathbf{R}^{2}$ & B & Sig. \\
\hline $\begin{array}{c}\text { Social } \\
\text { Support }\end{array}$ & .466 & .217 & .376 & .000 \\
\hline
\end{tabular}

This can be seen from the R-value of 0.466 with a significance level of 0.000 . This shows that the higher the social support received, the higher the work-life balance for working women.

In addition, it also obtained an $\mathrm{R}$ square value of 0.217 or $21.7 \%$, which indicates that the contribution of social support to the work-life balance of female workers during the work from home period is $21.7 \%$, and the unstandardized coefficient value is 0.376 , which indicates that for every increase of 1 point of support social services will also increase the worklifebalance by 0.376 .

\section{DISCUSSION}

This study aims to determine the contribution of social support to work-life balance for female workers during the work from home period. The results of this study indicate a contribution of social support to the work-life balance of female workers during the work from home period. The participants of study were female workers in private companies who worked from home.

The relationship between social support variables and work-life balance can be explained using the Conservation of resources theory (COR). Hobfoll [7] COR reveals that every individual has resources and tries to maintain them to avoid stress to create a balanced life. In the context of workers, Noorhidayat, Suwarsi \& Abdurrahman [18] suggest that work-life balance positively affects work stress. This shows that work stress will be reduced if supported by work-life balance. Furthermore, COR theory believes that one of the resources needed byworkers to achieve a balanced life is social support [11]. Social support is the perception of comfort, care, appreciation, or assistance obtained by individuals to directly feel the support provided, such as caring for and loved [16]. Kahn (1964) also suggests that roles as family and work members can often lead to inter-role conflict [19]. Resources thatcome from individuals, families, and the work environment can be positive resources that facilitate individuals to make adjustments between the two responsibilities. This is as stated by Novenia \& Ika [14] that the partner's social support both directly and indirectly is an essential role in helping individuals to be able to carry out their roles as workers and wives in maintaining individual psychological and physiological conditions.

The work from home phenomenon experienced by employees during the COVID-19 pandemic impacts workers because workers are required to perform two roles at one time. Singh \& Kumar [20] stated that work from home and office is different and separate. Different working conditions and times require adjustment. This adjustment will undoubtedly have a significant impact on positive and negative impacts.

When working from home, workers will be more flexible in managing their time, adjusting to work pressures, having better coordination to do household chores, and making it more manageable during pregnancy and childbirth. However, many employees cannot manage their time with this freedom, so they suffer from delays in tasks due to 
other priorities. The home atmosphere causes many mood swings compared to working from the office; when working from home, workers will find it difficult to concentratebecause the atmosphere is less supportive [20].

Workers who cannot provide boundaries between personal life and work-life will be more prone to experience work-life conflict [21]. This causes social support, especially family and people around, to be very important to help individuals achieve work-life balance by providing all forms of support to help individuals overcome all obstacles while carrying out these roles.

The results of this study are also similar to previous studies conducted by Nurhabiba [22], Fardianto \& Muzaaki [23], and Malik et al. [24]. The research results conducted by Nurhabiba [22] that social support contributes $24.5 \%$ to workers' worklife balance. Research also conducted by Fardianto \& Muzakki [23] that the support obtained from supervisors, co-workers, family, and organizational support positively influences workers' work-life balance. Malik et al. [24] that social support has a positive effect on the work-life balance of working women. This proves that both in the context of work from the office andwork from home, social support is a factor that can improve the work-life balance of working women.

In addition, the results of the descriptive analysis conducted on all research respondents found the social support of respondents in the very high category of $2.3 \%$, high $34.5 \%$, moderate $35.1 \%$, low $17.5 \%$, and very low $10.5 \%$. This categorization shows that female workers during the work from home period feel that they are receiving various forms of support from the people around them. The availability of people who are ready to help provides workers opportunities to carry out their roles in the scopeof work and outside work.

Sekaran [22] states that assistance and support can improve career development. The support provided by family members will provide a sense of security for women to have a career. Social support is a form of physical and psychological comfort provided by family and friends to create a sense of enthusiasm for workers to do work [24]. Aczel et al. [25] revealed that in work from home, social support from co-workers, more specifically family, is the most influential thing for workers in adjusting to a new work environment and unusual work dynamics.

Individuals who get social support in the form of information support, advice, real help, or the presence of other people will be better at dealing with a problem. The social support provided will make workers feel calmer and happier because they have anenvironment to help when they need help and get solutions to their problems. The problem is considered not a stressor, so adjustment to the family and work environments is better [26].

The descriptive analysis of the work-life balance variable showed that the respondents in this study had a very high work-life balance of $4 \%$, high $36 \%$, moderate $30 \%$, low $22 \%$, and very low $8 \%$. This shows that the work-life balance of female workers during the work from the home period is in the high category, indicating that although in the current work from home situation, workers can carry out both roles well, individuals have been able to make adjustments to new situations. Anugrah \& Priyambodo [5] stated that employees who implement work from home have flexible roles as workers and wives or parents. Employees who can provide clear boundaries between personal life and work-life will experience less stress due to the conditions they live. When work does not interfere with personal life or personal life interferes with work, individuals will quickly achieve a work-life balance because of the balance of both roles [5].

Achieving a work-life balance provides many benefits to workers where workers can achieve worklife balance, the quality of life will increase, avoid the bad effects of one role and be able to face the demands of the role, and have a lower stress level [5]. In addition to this, Grzywacz \& Carlson [27] also suggested that individuals who can achieve work-life balance can positively impact organizations, such as increasing organizational commitment, job satisfaction, and organizational citizenship behavior. A high work-life balance can also reduce an individual's tendency to resign and reduce absenteeismfrom work.

Results of additional research are analyzed by age. One of the factors that can affect an individual's work-life balance is age. Based on age, the highest level of work-life balance is for workers who are more than 40 yearsold. This is in line with the theory of Keeton et al. [28] that the older the individual, the easier it is for individuals to achieve work-life balance.

Results of additional research analysis based on the number of children. On average social support from female workers who do not have children to workers who have more than 2 are in the medium and high categories. Furthermore, the work-life balance of workers whodo not have children is in the medium category and workers who have 1 and 2 children are in the high category, and workers who have more than 2 children are in the medium and high categories. This shows that the number of 
children in this study affects increasing workers' work-life balance. This is not in line with Guest's statement that working women with children tend to experience imbalance more often. However, Guest also said that individuals who have good self-control would be calmer when facing existing problems to minimize conflicts between the two roles they carry out [29].

\section{CONCLUSION}

Based on the results of research that has been carried out regarding the contribution of social support towork-life balance for working women who work from home, it was found that there was a contribution of social support to work-life balance for female workers who worked from home by $21.7 \%$. This shows that social support is one of the variables that can improve workers' work-life balance. The higher the social support an individual gets, the higher the individual's work-life balance will be. On the other, the lower the social support, the lower the individual's work-life balance.

\section{AUTHORS CONTRIBUTIONS}

All researchers designed this research topic idea. Author 1 and writer 2 supervised the entire research process, from preparing the proposal to preparing the research report. Author 3 collects data, performs analysis, and makes reports. All researchers discussed for the final text.

\section{ACKNOWLEDGMENTS}

We thank all those who gave advice and agreed to this research. Thanks to Dr. Muhammad Tamar M.Si and Elvita Bellani, S.Psi., M.Sc, who provided comments and input during the research process. This work was supported by the Department of Psychology, Faculty of Medicine, Hasanuddin University and carried out under the psychology code of ethics of the Indonesian Psychological Association (HIMPSI).

\section{REFERENCES}

[1] Mustajab, D., Azies, B., Abdul, R., Andri, I., Muhammad, A.A., \& Muhammad, A.A., Working from home phenomenon as aneffort to prevent COVID-19 attacks and its impacts on work productivity, The International Journal of Applied Business, 2020, 4(1), pp. 13-21.

[2] Kalendesang, M. P., Hendro, B., \& Reginus, T.M., Hubungan konflik peran ganda perawat wanita sebagai care giver dengan stres kerja di ruangan rawat inap rumah sakit jiwa PROF. DR.V.L.Ratumbuysang provinsi Sulawesi utara, E-Journal Keperawatan, 2017, 5(1).
[3] Fisher, G. G., Bulger, C.A., \& Smith, C.S., Beyond work and family: A measure of work/nonwork interference and enhancement, Journal of Occupational Health Psychology, 2009, 14(4), pp. 441-456.

[4] Beauregard, T.A. \& Henry, C.L., Making the link between work-life balance practices and organizational performance, Human Resource Management, 2009, 19(1), pp. 9-22.

[5] Greenhaus, J.H., Collins, K.H., \& Shaw, J.D., (2003). The relation between work-family balance and quality of life, Journal of Vocational Behavior, 2003, 63, pp. 510-531.

[6] Maslichah, N.I. \& Kadarisman, H., Pengaruh work life balance dan lingkungan kerja terhadap kepuasan kerja karyawan. Jurnal Administrasi Bisnis, 2017, 49(1), pp. 60-68.

[7] Pichler, F., Determinants of work-life balance: Shortcomings in the contemporary measurement of WLB in large-scale surveys, Social Indicators Research, 2008, 92(3), pp. 449-469.

[8] Cutrona, C.E. \& Russell, D., The provisions of social relationships and adaptation to stress, Advances in Personal Relationships, 1987, 1, pp. 37-67.

[9] Adawiyah, R.A.R., Kecerdasan emosional, dukungan sosial dan kecenderungan burnout. Jurnal Psikologi Indonesia, 2013, 2(2), pp. 99107.

[10] Adnyaswari, N.A., \& Gusti, A.D.A., Pengaruh dukungan sosial dan burnout terhadap kinerja perawat rawat inap RSUP Sanglah, E-jurnal Manajemen Unud, 2017, 6(5), pp.2474-2500.

[11] Hobfoll, S. E., \& John, F., Conservation of social resources: social support resources theory, Journal of Social and Personal Relationships, 1990, 7, pp. 465-478.

[12] Poulose, S. \& Sudarsan, N., Work-life balance: A conceptual review, International Journal of Advances in Management and Economics, 2014, 3(2), pp.1-17.

[13] Greenhaus, J.H., Ziegert, J.C., \& Allen, T.D., When family-supportive supervisor matters: Relation between multiple sources of support and work-family balance, Journal of Vocational Behavior, 2012, pp. 266-275.

[14] Novenia, D. \& Ika, Z., R., Hubungan antara dukungan sosial suami dengan work- family balance pada guru wanita di SMA Negeri Kabupaten Purworejo, Jurnal Empati, 2017, 6(1), pp. 97-103.

[15] Sarafino, E.P. \& Smith, T.W., Health Psychology: Biopsychosocial Interactions $7^{\text {th }}$ ed., John Wiley \& Sons, 2011.

[16] Smet, B., Psikologi Kesehatan, Grasindo, 1994. 
[17] Ummah, W., Work life balance ditinjau dari model psikologis pekerja di Perusahan Garmen Yogyakarta, Skripsi. Fakultas ilmu psikologi dan ilmu sosial budaya, Universitas Islam Indonesia, 2018.

[18] Noorhidayat, F., Suwarsi, S., \& Abdurrahman, D., Pengaruh work-life balance terhadap stress kerja dan kinerja karyawan pada PT. Pln (Parsero) P2b Apb Jabar, Prosiding Manajemen, 2017, 3(2), pp. 1153-1159.

[19] Rosally, C. \& Jogi, Y., Pengaruh konflik peran, ketidakjelasan peran, dan komitmen organisasi terhadap kinerja auditor, Business Accounting Review, 2015, 3(2), pp. 31-40.

[20] Kumar, P.M.S. \& Aithal, P.S., Working from home a transition in the concept of workplace, International Journal of Current Research and Modern Education, 2016, 1(1), pp. 224-229.

[21] Kinman, G., Emotional labour and strain in "front-line" service employee, Journal of Managerial Psychology, 2008, 24(2), pp. 118 135.

[22] Nurhabiba, M., Social support terhadap work life balance pada karyawan, Ejournal Cognicia, 2020, 8(2), pp 277-295.

[23] Fardianto, N. A. \& Muzzaki, Support at work and home as a predictor of work life balance, Jurnal Manajemen dan Bisnis Indonesia, 2020, 6(2), pp. 144-153.

[24] Malik, M.I., Self, M.I., Gomez, S.F., Khan, N. \& Hussain, S., Balancing work and family through social support among working women in Pakistan, African Journal of Business Management, 2010, 4(13), pp. 2864-2870.

[25] Aczel, B., Kovacs, M., Vander, L.P., Szaszc, B., Researches working from home: Benefits and challenges, PLoS ONE, 2021, 16(3).

[26] Yanita, A. \& Zamralita, Persepsi perempuan primpara tentang dukungan suami dalam usaha menanggulangi gejala depresi pascasalin, Phronesis, 2001, 3(5), pp. 34-50.

[27] Ayuningtyas, L. \& Septarini, B. G., Hubungan family supportive supervision behaviors dengan work family balance pada wanita yang bekerja. Jurnal Psikologi Industri dan Organisasi, 2013 , 2(1), pp. 50-60.

[28] Keeton, K., Fenner, D.E., Johnson, T.R., \& Hayward, R.A., Predictors of physician career satisfaction, work-life balance, and burnout, Obstetrics \& Gynecology, 2007, 109(4), pp. 949-955.

[29] Guest, D., Perspectives on the study of worklife balance, Social Science Information, 2002, 41(2), pp. 255-279. 